\title{
Study of knowledge, attitude, practice of rational use of medicines among interns at Mc Gann teaching district hospital, Shivamogga- a descriptive cross-sectional study
}

\author{
Vedavathi Hanumaiah, Shreenivas Revankar, Abhishek C. P.*
}

Department of Pharmacology, Shivamogga Institute of Medical Sciences, Shivamogga, Karnataka, India

Received: 25 February 2021

Accepted: 31 March 2021

\section{*Correspondence:}

Dr. Abhishek C. P.,

Email: abhishekcptheunique@gmail.com

Copyright: (c) the author(s), publisher and licensee Medip Academy. This is an open-access article distributed under the terms of the Creative Commons Attribution Non-Commercial License, which permits unrestricted non-commercial use, distribution, and reproduction in any medium, provided the original work is properly cited.

\begin{abstract}
Background: Rational use of medicines requires that the patients receive medication appropriate to their clinical needs, in doses that meet their own individual requirements for an adequate period of lime, and at the lowest cost to them and to their community. Objective of the study were like descriptive cross- sectional study was conducted to determine and identify the level of knowledge, attitude and practice regarding rational use of medicines among the interns.

Methods: A validated structured questionnaire containing 19 questions regarding rational use of medicines in knowledge, attitude and practice (KAP) format was distributed in hand among 109 interns affiliated to this institution. Descriptive statistics were used to illustrate the results in the form of number and percentage.

Results: Out of 109 interns, 102 completed the questionnaire and were included in the final analysis. Majority of interns who participated in study were aware of the concept of rational use of medicine but the knowledge related to EML (essential medicines list), $\mathrm{P}$ drugs, schedule $\mathrm{H}$ drugs and number of FDCs (fixed dose combination) in EML was limited. Conclusions: As interns are future prescribers, they need to be aware of all the aspects of rational use of medicine and there is need to emphasise on learning module and training programs to ensure the interns have knowledge of rational use of medicines.
\end{abstract}

Keywords: Rational use of medicines, Essential medicines list, Fixed dose combination

\section{INTRODUCTION}

As per the WHO-'rational use of medicines requires that the patients receive medication appropriate to their clinical needs, in doses that meet their own individual requirements for an adequate period of lime, and at the lowest cost to them and to their community. ${ }^{1}$

Irrational prescribing is on the rise due to many factors like patient belief of "a pill for every ill", poor prescriber training, poor resource management, lack of adequate staff, aggressive pharmaceutical publicity, blindly following a prescribing pattern of senior doctors, inadequate knowledge. ${ }^{2}$
Irrational prescribing leads to poor health delivery may also put patients at risk and also result in wastage of scarce resources that could have been used to tackle other pressing health needs. ${ }^{3}$

Essential medicines list (EML) is an integral part of rational use of medicine and was defined by WHO in 1975 as a major step towards promoting rational use of medicine. In India, the ministry of health has revised the National list of essential medicines of India (NLEMI 2011) in 2015. It contains 376 medicines. EML have shown to improve the quality of prescribing and cost-effectiveness of health care delivery. ${ }^{4,5}$ 
This study is conducted to analyse the understanding about rational use of medicines and necessity for training required to adopt rational use of medicine.

\section{METHODS}

\section{Study design}

This descriptive cross-sectional study involved 109 interns affiliated to Mc Gann teaching district hospital, Shivamogga. The study was completed within duration of 1 month.

Informed consent was obtained from all the participants before conducting the study. The participants were free to deny from participating in the study. Before the commencement of the study, the questionnaires were distributed among 8 experts from various departments of this institution and content validity ratio (CVR) was determined. Only the questions with $\mathrm{CVR}>0.62$ were included. ${ }^{7}$ The knowledge, attitude and practice were evaluated by a semi-structured validated, pre-tested questionnaire in English language. These questionnaires were distributed by the investigator to all the study participants by hand. The participants were instructed to fill all the answers accurately as per their knowledge. The questionnaire consisted of 19 questions in total, designed to capture three main aspects of KAP study, namely "knowledge-based", "attitude-based" and "practicebased". 6,7

This study was conducted after receiving an ethical approval from the institutional ethics committee.

\section{Data analysis}

We performed Descriptive statistics to illustrate the results in form of numbers and percentage. All the information gathered from the questionnaire were coded into variables. Descriptive statistics were used to illustrate the results in the form of number and percentage. Results are reported according to the strengthening the reporting of observational studies in epidemiology reporting guidelines for observational studies.

\section{RESULTS}

\section{Assessment of knowledge of rational use of medicines among participants}

Out of 109 interns, 102 completed the questionnaire and were included in the final analysis. The knowledge about the rational use of medicines was tested among the interns. The results showed that $85.2 \%$ respondents were aware about the term rational use of medicine and $88.2 \%$ were aware of the term essential medicines and regarding NLEMI $19.6 \%$ were correct about time when the last EML list was revised and $9.8 \%$ were correct about the number of fixed dose combination in EML and $58.8 \%$ clinicians were able to name the parts of the prescription slip correctly. Though $56.8 \%$ respondents were aware of the term ' $\mathrm{P}$ ' drug concept, only 19.6 were aware about advantages of using P-drug for prescription. 39.2\% were aware of schedule $\mathrm{H}$ drugs. $88.2 \%$ were always aware of the ingredients of the drug you prescribe as shown in the Table 1 .

Table 1: Assessment of knowledge regarding rational use of medicine.

\begin{tabular}{|c|c|c|}
\hline \multirow[t]{2}{*}{ Statements } & \multicolumn{2}{|c|}{$\begin{array}{l}\text { No. of respondents } \\
(\%)\end{array}$} \\
\hline & Yes & No \\
\hline $\begin{array}{l}\text { Are you aware of the term } \\
\text { rational use of medicine? }\end{array}$ & $87(85.2)$ & $15(14.8)$ \\
\hline $\begin{array}{l}\text { Are you aware of the term } \\
\text { essential medicines? }\end{array}$ & $90(88.2)$ & $12(11.8)$ \\
\hline $\begin{array}{l}\text { Are you aware of the term } \\
\text { P-drugs? }\end{array}$ & $58(56.8)$ & $44(43.2)$ \\
\hline $\begin{array}{l}\text { When was the last EML list } \\
\text { revised? (correct answer - } \\
\text { Yes/No) }\end{array}$ & $20(19.6)$ & 82 (81.4) \\
\hline $\begin{array}{l}\text { Can you name the parts of a } \\
\text { prescription? }\end{array}$ & $60(58.8)$ & $42(41.2)$ \\
\hline $\begin{array}{l}\text { Are you aware of } \\
\text { advantages of using P-drug } \\
\text { for prescription? }\end{array}$ & 20 (19.6) & $82(80.4)$ \\
\hline $\begin{array}{l}\text { Do you know the number of } \\
\text { fixed dose combination } \\
\text { included in EML? }\end{array}$ & $10(9.8)$ & $92(90.2)$ \\
\hline $\begin{array}{l}\text { Are you aware of Schedule } \\
\text { H drugs? }\end{array}$ & $40(39.2)$ & $62(60.8)$ \\
\hline $\begin{array}{l}\text { Are you always aware of the } \\
\text { ingredients of the drug you } \\
\text { prescribe }\end{array}$ & $90(88.2)$ & $12(11.8)$ \\
\hline
\end{tabular}

Assessment of attitude of rational use of medicines among participants

The attitude of interns towards the rational use of medicines was evaluated based upon their training during the under graduate course. When it comes to advantages of rational use of medicine majority of them agreed that it would minimize adverse drug reaction (ADR), avoid development of resistance, more safe, cost-effective, proper treatment (Table 3 ) and $98 \%$ respondents said they require regular training about rational use of medicine after MBBS course.

\section{Assessment of practice of rational use of medicines among participants}

Questions were directed to assess the practice domain of rational use of medicines among interns, majority of respondents $(68.6 \%)$ prescribed drugs by generic names while $17.6 \%$ of respondents prescribed drugs by brand names and $11.7 \%$ prescribed by both generic as well as brand names (Table 2) nearly $85.8 \%$ interns said they prescribe essential medicines but only $9.8 \%$ prescribed FDC from the EML. 
Table 2: Assessment of practice regarding of rational use of medicine among interns.

\begin{tabular}{|c|c|c|}
\hline Statements & \multicolumn{2}{|c|}{ No. of respondents $(\%)$} \\
\hline \multirow{2}{*}{ Do you prescribe essential medicines? } & Yes & $86(85.8)$ \\
\hline & No & $16(14.2)$ \\
\hline \multirow{3}{*}{ By which name do you prescribe drugs } & Generic & $70(68.6)$ \\
\hline & Brand name & $18(17.6)$ \\
\hline & Both & $12(11.7)$ \\
\hline \multirow{2}{*}{ Do you think there should be a EML in each department } & Yes & $91(89.18)$ \\
\hline & No & $11(10.7)$ \\
\hline \multirow{2}{*}{ Do you always prescribe FDC from the EML } & Yes & $10(9.8)$ \\
\hline & No & $92(90.2)$ \\
\hline \multirow{2}{*}{$\begin{array}{l}\text { Do you think regular training is needed about rational use of } \\
\text { medicine after MBBS course }\end{array}$} & Yes & $98(96.1)$ \\
\hline & No & $04(3.9)$ \\
\hline
\end{tabular}

Table 3: Questionnaire-rational use of medicines.

\begin{tabular}{|llllll|} 
Variables & $\begin{array}{l}\text { Strongly } \\
\text { agree }(\boldsymbol{\%})\end{array}$ & $\begin{array}{l}\text { Agree } \\
(\%)\end{array}$ & $\begin{array}{l}\text { Neutral } \\
(\%)\end{array}$ & $\begin{array}{l}\text { Disagree } \\
(\%)\end{array}$ & $\begin{array}{l}\text { Strongly } \\
\text { disagree }(\%)\end{array}$ \\
\hline Minimize adverse drug reaction (ADR) & 40 & 32 & 28 & - & - \\
\hline Avoid development of resistance & 49 & 33 & 18 & - & - \\
\hline More safe & 35 & 36 & 29 & - & - \\
\hline Cost-effective & 56 & 29 & 15 & - & - \\
\hline Proper treatment & 39 & 33 & 28 & - & - \\
\hline
\end{tabular}

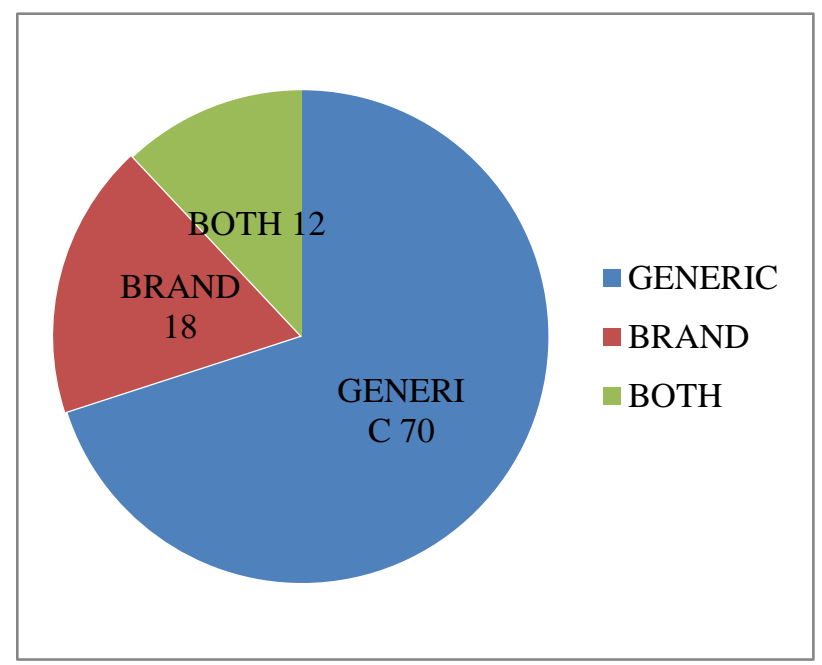

Figure 1: Prescribing pattern among interns.

\section{DISCUSSION}

This study was conducted with a motive to understand the level of understanding and the knowledge the interns have regarding the rational use of medicines in a tertiary care teaching hospital. The questions were directed towards three major domains: knowledge, attitude and practice. It was found that overall knowledge, attitude and practice regarding rational use of medicines was found to be limited among the interns.

Training in rational use of medicines is more likely to be effective if it takes into consideration outlook and expertise and is targeted to the prescribing requirements. ${ }^{8,9}$ This study would take into consideration existing knowledge and understanding of interns about various issues concerned with rational use of medicines and would guide us in training them better in our institute. Hence, assessing knowledge of rational use of medicines among them in such set-up would be helpful in promoting rational use of medicines and improving health care services. In the present study, majority of respondents were aware about most of the issues concerned with rational use of medicines addressed in the questionnaire which seems to be a positive finding. But being future prescribers, all of them need to

have correct knowledge about all the issues addressed. Majority of respondents seem to be aware of the concept of essential medicine since it is an old concept. The findings are similar to the previous study conducted by Mahajan et al. ${ }^{13}$ This clearly indicates lack of measures to update professional knowledge. Regarding essential medicines, not only selection but also its appropriate use is necessary for upgrading quality of health care. Some studies have reported improvement in the quality of health care following use of NLEM and standard treatment guidelines. ${ }^{10-12}$ Hence, it is essential to adopt measures that will encourage their use. Various studies have revealed that prescribing medicines by brand name has become a routine practice. Prescribing by generic name should be encouraged at an early stage of medical practice to promote rational use of medicines. It is encouraging to know that almost all the respondents were always aware of the ingredients of the drug prescribed. ${ }^{13,14}$ Even though medical students are exposed to this in their pharmacology curriculum during MBBS, lack of knowledge regarding $\mathrm{P}$ - 
drug concept indicates that the P-drug concept has remained confined to pharmacology and has not become popular among clinicians. Involvement of clinicians is vital if the P-drug concept is to succeed. ${ }^{15}$ In one study, physicians admitted that their prescribing decision are influenced by MR and they are bound to prescribe certain medicine at the cost of getting some incentives in the form of free samples, gifts or various kinds of supports. Though, it is now a well-accepted fact that rational use of medicines is an important issue and that doctors are the major prescribers of medicines, teaching of rational use of medicines is not given much importance in most of the medical colleges. This can be considered as a major cause of errors in prescribing with its adverse consequences subsequently. Therefore, sincere efforts are required to promote rational use of medicines among clinicians to avoid irrational prescribing. WHO, has suggested future strategy and directions regarding rational use of medicines like close coordination between process for the development of standard treatment guidelines and efforts to improve quality use of medicine, continued emphasis on the inclusion of EM concept in undergraduate and postgraduate medical curricula and emphasis on the effective utilization of drug and therapeutic committees at regional and district levels. In conclusion, it is encouraging finding that higher percentages of respondents were aware about EM and also prescribed it. But level of understanding related to P-drug concept and existence of essential medicine list are much below par. Considering the fact that respondents are future prescribers they should be aware of all aspects about rational use of medicines and improper knowledge in certain areas of rational use of medicines is a matter of concern that needs to be addressed. ${ }^{14,15}$ Although the concept of rational use of medicines is included in undergraduate curriculum more vigorous training regarding rational use of medicines is required to strengthen the mechanism for continuing professional development of clinicians to update their knowledge and skills to prescribe rationally.

\section{CONCLUSION}

Majority of Interns were aware about various issues concerned with rational use of medicine but the knowledge related to EML, $\mathrm{P}$ drugs, schedule $\mathrm{H}$ drugs and number of FDCs in EML was limited. As interns are future prescribers, they need to be aware of all the aspects of rational use of medicine. Inadequate/improper knowledge in the above areas is a matter of concern and needs to be addressed. Similar studies should be done at medical colleges, district hospitals and health care centres, so that the lacunae in knowledge, attitude and practice of rational use of medicine can be identified and appropriate corrective measures taken which will help in improving the quality of health care.

\section{ACKNOWLEDGEMENTS}

The authors would like to thanks to the management of Shivamogga institute of medical sciences and Mc Gann teaching hospital-Shivamogga for their help and cooperation through the study.

Funding: No funding sources

Conflict of interest: None declared

Ethical approval: The study was approved by the Institutional Ethics Committee

\section{REFERENCES}

1. World Health Organization: Selection and rational use of medicines. Available at: http://www.who.int/mediacentre/ factsheets/fs338/en/. Accessed on 20 December 2020.

2. The Role of Education in the Rational use of medicines. SEARO Technical Publication Series No. 4 World Health Organization, Regional Office for South-East Asia. Available at: https://apps.who.int/iris/handle/10665/205994. Accessed on 20 December 2020

3. Susheela F, Goruntla N, Bhupalam PK, Veerabhadrappa KV, Sahithi B, Ishrar SMG. Assessment of knowledge, attitude, and practice toward responsible self-medication among students of pharmacy colleges located in Anantapur district, Andhra Pradesh, India. J Educ Health Promot. 2018;7:96.

4. Hooli TV, Srikanth, Somashekara SC, Suraj B. Knowledge, attitude, practice of rational use of medicines among junior residents in a tertiary care hospital. Int J Basic Clin Pharmacol. 2017;6:2001-4.

5. Rational use of drugs-Report of the Conference of Experts Nairobi. 1985.

6. Holloway K. Promoting rational use of medicines. Contact a publication of world council of churches. 2006;183:2-3.

7. Lawshe $\mathrm{CH}$. A quantitative approach to content validity. Personnel psychol. 1975;28(4):563-75.

8. The Selection of Essential Medicines-Perspectives WHO policies. 2002;1-6.

9. Manikandan S, Gitanjali B. National list of essential medicines of India: The way forward. J Postgr Med. 2012;58(1):68-72.

10. De Vries TP, Henning RH, Horgerzeil HV, Fresle HV. World Health Organization: Guide to good prescribing. Geneva, WHO. 1994;14-8.

11. Sontakke SD, Budania RJ, Paranjape SG. Evaluation of knowledge, attitude and behavior about rational use of medicines in second year medical students. IJBCP. 2013;2(5):617-21.

12. Aronson JK. A prescription for better prescribing. $\mathrm{Br}$ J Clin Pharmacol. 2006;61(5):487-91.

13. Mahajan R, Singh NR, Singh J, Dixit A, Jain A, Gupta A. Current scenario of attitude and knowledge of physicians about rational prescription: A novel crosssectional study. J Pharm Bioalln Sci. 2010;2(2):132-6.

14. Kar SS, Pradhan HS, Mohanta G. Concept of Essential Medicines and Rational Use in Public Health. Indian J Community Med. 2010;35(1):10-3. 
15. Hogerzeil HV. The concept of essential medicines: lesson for rich countries. BMJ. 2004;329:(7475)116972.

16. Rathod R, Rathod A, Gupta VK, Ahmed T, Jha RK, Gaikwad N. Audit in Dermatology for Rational Prescribing. RJPBCS. 2012;3(3):518-24.

17. The selection and use of Essential Medicines-Report of the WHO expert committee. Geneva, WHO. 2011. Available at: https://www.who.int/medicines/ publications/essentialmeds_committeereports/en/. Accessed on 20 December 2020.

Cite this article as: Hanumaiah V, Revankar S, Abhishek CP. Study of knowledge, attitude, practice of rational use of medicines among interns at Mc Gann teaching district hospital, Shivamogga-a descriptive cross-sectional study. Int J Basic Clin Pharmacol 2021;10:512-6. 